DOI https://doi.org/10.30525/978-9934-26-073-5-2-19

\title{
ОРІЕНТОВАНІ НАПРЯМИ АНГЛОМОВНОЇ ЛІНГВО- Й НЕЙРОКОГНІТОЛОГІЇ: ДОСВІД РЕКОНСТРУКЦІЇ СИСТЕМИ КОНЦЕПТІВ В ІНДИВІДУАЛЬНО-АВТОРСЬКОМУ АСПЕКТІ
}

\author{
Шкляревський В. Г. \\ інженер-програміст лабораторї комп 'ютерної лінгвістики, \\ здобувач кафедри англійської філологї, перекладу і філософії мови \\ імені професора О. М. Мороховського \\ Київського начіонального лінгвістичного університету \\ м. Київ, Україна
}

Рушійною силою розвитку сучасних лінгвістичних студій є технологізація емпіричного матеріалу з огляду на поєднання традиційних i новітніх методів дослідження [2, с. 43]. Це стосується, зокрема, застосування корпусних методів у лінгвокогнітивних дослідженнях, що може сприяти одержанню нетривіальних результатів наукового пошуку. Саме тому на сьогодні взаємозв'язок корпусної лінгвістики і лінгвокогнітології вважається цілком можливим і ефективним.

Пропоноване дослідження присвячене прогностичному окресленню напрямів сучасної лінгво- та нейрокогнітології шляхом аналізу системи концептів, реконструйованої із текстів монографій англомовних когнітологів завдяки поєднанню корпусного методу [3] й методики когнітивного мапування [5, p. 3] Емпіричний матеріал дослідження складає створений нами корпус англомовних текстів 3 лінгво- та нейрокогнітології (КАТЛтаНК), до якого включено праці Джорджа Лакоффа, Марка Л. Джонсона, Марка Тернера та Джерома А. Фельдмана [4, с. 53]. Укладений корпус текстів містить понад 1356124 млн. слововживань і 53681 слів.

Ключові концепти, актуалізовані в текстах монографій зазначених дослідників, вербалізовано двома групами лексики: термінами, що належать до предметної галузі лінгво- та нейрокогнітології, і загальнонауковими термінами. Методику когнітивного мапування було застосовано для унаочнення результатів аналізу семантичних взаємозв'язків цих термінів і реконструкції окремих систем концептів або підкорпусів текстів конкретних авторів. Для встановлення зв'язків частотних термінів використано прийом екстракції колокацій, сталих сполучень двох слів, які не обов'язково розташовані в тексті поспіль [1, с. 22]. 
Визначення сполучуваності термінів грунтується на результатах статистичного аналізу, з використанням морфологічної розмітки. Цей метод використовується в корпусній лінгвістиці для пошуку словосполучень, а також різного роду зв'язків між словами і дозволяє визначити, наскільки значущою є зустрічність двох лем на підставі порівняння частоти спільної появи двох слів 3 добутком частот їх незалежної появи в тексті.

Застосування інструментарію для опрацювання природної мови бібліотеки NLTK [6], зокрема таких модулів опрацювання текстів, як токенізація, нормалізація, морфологічна розмітка, лематизація, видалення стоп-слів, статистичний аналіз (частота розподілу слів), а також автоматична екстракція колокацій частотних слів дозволяють мінімізувати суб'єктивність виокремлення релевантних термінів 3 текстів корпусу.

Основні вузли когнітивної мапи текстів презентовані ключовими концептами досліджуваної предметної галузі, вербалізованими високочастотними словами, які характеризуються регулярними змістовими зв'язками з актуалізаторами інших ключових концептів, що належать до різних рівнів когнітивної мапи. Встановлення ключових концептів i реконструкцію їх системи здійснено на підставі даних частотних ідіословників, складених нами на основі досліджуваного корпусу текстів.

Найчастотнішими у працях названих вище дослідників $є$ релевантні для лінгво- та нейрокогнітології терміни, що корелюють із ядром системи концептів цих предметних галузей. Так, найчастотніше словоконцепт в працях Дж. А. Фельдмана - це language (888), М. Джонсона meaning (1614), Дж. Лакоффа - metaphor (2599), М. Тернера space (2399). Усі встановлені слова-концепти, відіграють важливу роль в тематиці досліджуваних текстів. Зона перетину частотних ідіословників охоплює понад половини списків найчастотніших слів, i розбіжність між показниками входження слів різних авторів до зони перетину є неістотною.

Активність певного ключового концепту, типового для окремого автора чи авторів, у покритті тексту семантичними зв'язками залежить від загального обсягу й тематичної однорідності колекції текстів. Найбільшою активністю характеризується глобальний текстовий концепт, що є вершиною ієрархії концептів на авторській або загальній когнітивній мапі, відтвореній на матеріалі текстів корпусу. Глобальний текстовий концепт має максимальну кількість регулярних змістових зв'язків з іншими концептами, вербалізованими в окремому тексті або корпусі текстів. До прикладу, глобальний текстовий концепт у всьому 
підкорпусі текстів Дж. Лакоффа-М. Джонсона, як і у книзі «The Political Mind», вербалізується словом metaphor, це підтверджується показниками частотності вживання в досліджуваних текстах, а також кількістю та різноманіттям утворених з цим словом словосполучень.

3 розвитком авторської наукової концепції система концептів тієї чи іншого предметної галузі набуває певних змін. На актуалізацію змістових зв'язків ключових концептів предметної галузі впливають мовна особистість автора, його ідіостиль та конкретна проблематика тексту або корпусу текстів. Суттєві зміни концепції науковців відбиваються як у системі концептів, так і в реєстрі частотних ідіословників, розподілі частот слів, що вербалізують певні концепти. Результати змін в авторській системі концептів відображає динамічна когнітивна мапа, укладена на матеріалі текстів, опублікованих протягом певного проміжку часу. Динамічна когнітивна мапа фіксує перерозподіл ключових концептів, зміщення їх змістових зв'язків та появу нових текстових концептів у системі автора або авторів.

За матеріалами корпусу англомовних текстів 3 лінгво- та нейрокогнітології найбільш кардинальних змін у часі зазнає динамічна когнітивна мапа М. Джонсона через найбільшу віддаленість включених до корпусу його текстів («The Body in the Mind», $1987 \mathrm{i}$ «The Meaning of the Body», 2007). Динамічна мапа демонструє, як скорочуються частотність уживань термінів на позначення таких концептів, як theory, understanding, force, imagination i збільшуються поява термінів experience, concept, metaphor, way, object. Однак глобальним текстовим концептом у підкорпусі текстів М. Джонсона залишається концепт meaning, що свідчить про існування загальної наукової концепції, яка поєднує досліджувані тексти монографій цього автора. У відтвореній на матеріалі підкорпусу концептуальній системі М. Джонсона спостерігається сталий розвиток концептів, лексикалізваних лінгвістичними та загальнонауковими термінами із збереженням фокусу на лінгвістичній термінології, про що свідчить сталість позиції глобального концепту meaning.

Динамічна когнітивна мапа, укладена на основі колекції текстів Дж. Лакоффа, характеризується послабленням активності ключових концептів, вербалізованих лінгвістичними та загальнонауковими термінами (model, category, world, thing, experience, time), і поступовим зміщенням у напрямку домену соціального життя людини (freedom, life), зокрема появою нових змістових зв'язків ключових концептів, характерних для зсуву в бік домену когнітивної соціології (human, freedom, people). 
Найбільш розгалуженою за структурою є динамічна когнітивна мапа М. Тернера, яка характеризується найбільшим охопленням ключових концептів, характерних для домену когнітології. Розвиток концепції М. Тернера характеризується зменшенням кількості змістових зв'язків загально-лінгвістичних термінів (story, language, metaphor) і значним розгалуженням термінів предметної галузі когнітології (blend, integration network, frame, meaning), а також використанням у ролі глобальних текстових концептів лише когнітологічних термінів (space, blend). На відміну від кардинальних змін у когнітивних мапах М. Джонсона зміни в концетуальній структурі М. Тернера мають поступальний характер, про що свідчить збереження вузлів у когнітивній мапі і зміщення змістових зв'язків у напрямку домену когнітивної психології.

Подібно до системи концептів М. Тернера у частотному ідіословнику підкорпусу Дж. А. Фельдмана ключові концепти meaning $i$ metaphor не належать до високочастотних, а у побудованій когнітивній мапі на матеріалі одного тексту концепт meaning знаходиться на другому рівні похідних і metaphor - на четвертому. Водночас терміносполучення, у яких вербалізуються ці концепти у тексті Дж. А. Фельдмана, $\epsilon$ характерними також для підкорпусів М. Тернера та Дж. Лакоффа за даними КАТЛтаНК.

На підставі результатів когнітивного мапування корпусу англомовних текстів з лінгво- та нейрокогнітології доходимо висновку, що аналізовані праці Дж. Лакоффа та його співавторів у своїй динаміці вписуються в когнітивно-соціологічний напрям зазначених предметних галузей, монографічне видання М. Джонсона, скоріше, належить до онтологічного або власне когнітивноого вектору досліджень, а праці М. Тернера до когнітивно-психологічного напряму сучасних когнітивних студій. Щодо Дж. А. Фельдмана, то за результатами когнітивного мапування тексту його праці, це - проміжна позиція між онтологічним і когнітивнопсихологічним напрямами.

\section{Література:}

1. Бобкова Т.В. Корпусно-базований підхід до мережевого моделювання значення тексту. Вісник Донецького національного університету. Серія Б. Гуманітарні науки. 2014. № 1-2. С. 20-25.

2. Воробьёва О.П. Лингвистика сегодня: реинтерпретация эпистемы. Вісник Київського національного лінгвістичного університету. Серія Філологія. 2013. Т.16, № 2. С. 41- 47. URL: http://nbuv.gov.ua/UJRN/ Vknlu_fil_2013_16_2_8(дата звернення: 18.04.21) 
3. Кибрик А. А. Мультимодальная лингвистика. Когнитивные исследования. 2010. IV. С. 134-15.

4. Шкляревський В.Г. Використання когнітивного мапування для встановлення тенденцій розвитку лінгвокогнітології. Science and Education a New Dimension. Philology. 2020. VIII(66), 218. C. 53-57. URL: www.seanewdim.com (дата звернення: 18.04.21)

5. Cleary B., Exton Ch. Assisting concept assignment using probabilistic classification and cognitive mapping. Proceedings of 19th Annual Psychology of Programming Workshop. 2006. URL: http://hdl.handle.net/10344/2168 (дата звернення: 18.04.21)

6. Natural Language Toolkit. NLTK 3.6 documentation. URL: http://www.nltk.org/ (дата звернення: 18.04.21) 